\title{
RUCHY MIEJSKIE: KONFLIKT JAKO STRATEGIA ROZWIAZZYWANIA PROBLEMÓW SPOŁECZNYCH MIASTA
}

\section{CIVIC MOVEMENTS: CONFLICT AS A STRATEGY FOR RESOLVING SOCIAL ISSUES OF THE CITY}

\author{
Justyna Tomczyk ${ }^{1(\mathrm{~A}, \mathrm{~B}, \mathrm{C}, \mathrm{D}, \mathrm{E}, \mathrm{F}, \mathrm{G})}$
}

${ }^{1}$ Uniwersytet Pedagogiczny im. KEN w Krakowie

Tomczyk J. (2017), Ruchy miejskie: konflikt jako strategia rozwiq̨zywania problemów społecznych miasta. Rozprawy Społeczne, 11 (2), s. 14-22.

Wkład autorów:

A. Zaplanowanie badań

B. Zebranie danych

C. Dane - analiza i statystyki

D. Interpretacja danych

E. Przygotowanie artykułu

F. Wyszukiwanie i analiza

literatury

G. Zebranie funduszy

Tabele: 0

Ryciny: 0

Literatura: 31

Otrzymano: 16.09 .2016

Zaakceptowano: 16.11.2016

\begin{abstract}
Streszczenie
Artykuł przedstawia - w oparciu o socjologiczna teorię konfliktu - znaczenie, role i funkcje ruchów miejskich w procesie artykułowania i rozwiązywania problemów społecznych, które pojawiają się w mieście i dotyczą jego mieszkańców. Zastosowanie podejścia konfliktowego jest podwójnie uzasadnione. Po pierwsze miasto jest traktowane (za D. Harvey'em) jako obszar konfliktów i napięć, które mają podłoże ekonomiczne i klasowe. Po drugie ruchy miejskie są rozumiane (za A. Touraine'em) jako przejaw konfliktu społecznego, polegającego na podziale społeczeństwa na dwie opozycyjne wobec siebie grupy, poróżnione przez obiekt walki, nad którym próbują przejąć kontrolę. Cechą konstytutywną tego konfliktu jest to, że dotyczy on realnych (zorganizowanych) aktorów społecznych oraz jest ukierunkowany na artykulację i realizację interesów zbiorowości miejskiej. Konflikt aktywizuje mieszkańców, jest formą partycypacji obywatelskiej, narzędziem zmiany i modernizacji, instrumentem przekształceń w obrębie struktury i kultury miejskiej.
\end{abstract}

Słowa kluczowe: ruch miejski, konflikt, problem społeczny

\section{Summary}

Basing on the sociological theory of conflict, the article presents the significance, roles and functions of civic movements in the process of articulating and solving social problems which emerge in the city and concern its inhabitants. The use of the conflict approach has double justification. Firstly, the city is treated (following D. Harvey) as an area of conflicts and tensions that have economic and social class roots. Secondly, civic movements are understood (following Touraine) as a manifestation of a social conflict, consisting in the division of society into two opposing groups, disunited by the subject of the fight over which they try to take control. The constitutive feature of this conflict is the fact that it refers to real (organised) social actors and is directed at the articulation and realisation of interests of the urban community. The conflict activates inhabitants as it is a form of a civic participation, a tool of change and modernisation, an instrument of transformations within the urban structure and culture.

Keywords: civic movement, conflict, social problem

\section{Wprowadzenie: ruchy miejskie - miasto jako obiekt myślenia i działania}

Kiedy w 1961 roku Jane Jacobs opublikowała książkę Śmierć i życie wielkich miast Ameryki, nie mogła przypuszczać, że ta praca stanie się początkiem dwóch rewelatorskich (a jednocześnie rewolucyjnych) trendów myślenia o mieście. Pierwszy trend - rozwinięty na krytycznym gruncie książki - traktuje miasto jako obszar, który należy logicznie zagospodarować, kierując się przy tym interesem zwykłych obywateli, nie zaś znaczących i lobbujących aktorów ekonomicznych. Drugi trend - rozwijany kontekstualnie - eksponuje rolę ruchów miejskich w zarządzaniu miastem i dostosowywaniu go do potrzeb ludności przez: rozsądne planowanie administracyjne, projektowanie funkcjonalnej i wygodnej przestrzeni, dobrą organizację mieszkalnictwa, regulację ruchu drogowego. Punktem

Mimo iż wizja miasta roztaczana w niniejszej książce jest często uznawana za idealistyczna, a tym samym podawana w wątpliwość, kwestionowana, a niekiedy odrzucana w oficjalnym (naukowym) dyskursie, to należy podkreślić istotność wskazanego podejścia. Jane Jacobs, okrzyknięta medialnie „babcią hipsterów” i „matką chrzestną ruchów miejskich”, zwraca uwagę, że miasto powinno należeć do mieszkańców, którzy mają prawo decydować o mieście i określać warunki jego funkcjonowania. Przeciwstawiając się hegemonii władzy deweloperów, polityków i urbanistów, Jacobs staje się inicjatorkę krytycznej debaty o mieście - jako przestrzeni konstruowanej społecznie, politycznie, ekonomicznie.

Adres korespondencyjny: Justyna Tomczyk, Uniwersytet Pedagogiczny im. KEN w Krakowie, ul. Podchorążych 2, 30-084 Kraków, e-mail: justynatomczyk1@wp.pl, tel.: 126626223

Copyright by: Państwowa Szkoła Wyższa im. Papieża Jana Pawła II w Białej Podlaskiej, Justyna Tomczyk

Czasopismo Open Access, wszystkie artykuły udostępniane są na mocy licencji Creative Commons Uznanie autorstwa-użycie niekomercyjne-na tych samych warunkach 4.0 Międzynarodowe (CC BY-NC-SA 4.0, http://creativecommons.org/licenses/by-nc-sa/4.0/). 
wyjścia dla logistyki miejskiej powinno być usprawnienie, a jednocześnie uatrakcyjnienie życia codziennego społeczności miejskiej (szybka i skuteczna realizacja interesów, potrzeb, celów mieszkańców, możliwość uczestnictwa w sferze publicznej i prywatnej, poszerzona oferta rekreacyjna i rozrywkowa). Jacobs postuluje dynamizowanie miasta poprzez odpowiedni rozkład zabudowań, recykling budynków i gruntów, częściową gentryfikację, rewitalizację terenów śródmiejskich. Wszystkie zabiegi uszlachetniające powinny być dokonywane ze szczególnym uwzględnieniem tych przestrzeni, gdzie ludzie mogą się spotykać, nawiązywać kontakty, rozwijać więzi międzyludzkie i sieci wsparcia, budować kapitał obywatelski. Odpowiednie zagospodarowanie $\mathrm{w}$ połączeniu z odpowiedzialnym zarządzaniem stanowi o sile oraz potencjale miasta, co z kolei bezpośrednio przekłada się na skuteczność w rozwiązywaniu pojawiajacych się tam problemów, zagrożeń, patologii. Jak słusznie podkreśla Jacobs, „udany miejski rejon to przestrzeń, która na bieżąco stawia czoła swoim problemom i nie daje się zniszczyć" (Jacobs 2014, s. 127).

Problemy społeczne, które rodzą się w mieście i mają miejski charakter (tzn. wynikają z urbanizacji lub segmentacji przestrzeni, są konsekwencją miejskich wzorów konsumpcji lub polityki lokalnej), stanowią asumpt do powstania ruchów miejskich ukierunkowanych m.in. na poprawę warunków mieszkaniowych, kwestionowanie inicjatyw budowlanych niszczących charakter zabudowań, obronę parków i terenów zielonych, walkę z z zanieczyszczeniem środowiska naturalnego (Giddens 2006). Problemy te mogą być rozwiązane tylko wtedy, gdy zostaną podjęte $\mathrm{w}$ dyskursie publicznym oraz stworzą tzw. ramę interpretacyjną, która zapoczątkuje i podtrzyma działania zbiorowe (Griswold 2013). Rama interpretacyjna oznacza w tym przypadku traktowanie miasta jako obiektu kolektywnego myślenia i działania, jako żywej i plastycznej tkanki poddającej się formowaniu, sukcesywnym przekształceniom. Proces (re)konstruowania miasta odbywa się przy udziale ruchów miejskich, które przyczyniają się do istotnych zmian elementów systemu miejskiego (polityki, kultury, technologii, mediów, komunikacji interpersonalnej itd.). Dzieje się tak dlatego, iż ruchy te stanowią ogół praktyk, które są wypadkową pozycji aktorów zarówno w mezzostrukturze miejskiej, jak również w makro- i megastrukturze społecznej. Praktyki te zmierzają obiektywnie w stronę wywołania zmian strukturalnych bądź zmodyfikowania stosunków władzy (Castells 1982). Podstawowym obszarem aktywności ruchów miejskich jest system miejski (urban system) oraz powiązane z nim podsystemy. Manuel Castells definiuje system miejski w sposób podwójnie złożony. Po pierwsze w odniesieniu do struktury społecznej - jako relacje między aktorami społecznymi, które są kształtowane przez pozycje zajmowane przez tych aktorów w systemie politycznym, prawnym, ekonomicznym, ideologicznym. Po drugie w odniesieniu do organizacji społecznej, ukazując tym samym związek z historycznie wykształconymi formami społecznymi (Castells 1982). Zmiany $\mathrm{w}$ systemie miejskim łączą się $\mathrm{z}$ oddziaływaniem na układy polityki i władzy, czyli takim wywieraniu wpływu na podmioty zarządzające miastem (np. samorząd, biznes, agendy bankowe i komercyjne), który skutkuje realizacją określonych interesów bądź żądań mieszkańców.

Aktywność ruchów miejskich zmierza do wyartykułowania i rozwiązania problemów pojawiających się w mieście i dotyczących jego mieszkańców. Zakres, zasięg, rodzaj tych problemów różnicuje się w czasie i przestrzeni, co jest spowodowane licznymi przemianami urbanizacyjnymi, zwłaszcza z rozwojem aglomeracji przemysłowych (w tym budownictwa i infrastruktury). Wśród najistotniejszych należy wymienić: zróżnicowanie ról społecznych i podziału pracy, powstanie nowych instytucji i organizacji, przekształcenie struktur klasowych i warstwowych, przewartościowania w systemie aksjonormatywnym, przeobrażenia władzy i elit politycznych. Zmiany te są następstwem charakterystycznych dla XX wieku procesów emancypacyjnych i modernizacyjnych polegających na upolitycznieniu pozapolitycznych obszarów życia codziennego (np. seksu, macierzyństwa, żywności, czasu wolnego, ekologii, ubrania, mieszkania). Jak zaznacza Barbara Sterniczuk, „nowe miejskie problemy to nie problemy integracji czy akulturalizacji [...], to nie problemy mogące być rozwiązane na poziomie i środkami lokalnymi, lecz zagadnienia wskazujące na wyraźne upolitycznienie się problemów miejskich w państwach kapitalistycznych. Jest to wynik rozwoju systemu ekonomicznego tych państw, wynik przestrzennej i społecznej koncentracji środków produkcji, wynik koncentracji ludności w miastach. Te procesy powodują narastanie sprzeczności w systemie miejskim, przyczyniają się także do wzrostu interwencji państwa $\mathrm{w}$ procesy produkcji i dystrybucji dóbr miejskich" (Sterniczuk 1979, s. 99). Liczne sprzeczności w dostępie i korzystaniu z oferty miejskiej, a w następstwie wynikające $\mathrm{z}$ nich konflikty grupowe, stają się punktem odniesienia dla powstania i rozwoju ruchów miejskich. Są one - według Castellsa motorem pozytywnych zmian i innowacji w mieście (Castells 1982), instrumentem zmiany i modernizacji. Idea ruchów miejskich opiera się na przekonaniu, iż miasto jest soczewką odbijającą społeczeństwo jako pewną całość. Tym samym problemy miejskie powinny być traktowane jako ogólnospołeczne i rozwiązywane przy użyciu wszystkich ogólnodostępnych środków politycznych i ekonomicznych. Podejście to wyrasta z założenia, iż bycie mieszkańcem miasta stanowi o byciu obywatelem miejskim, z czym wiążą się określone prawa i obowiązki (m.in. troska o los miasta, czynny udział w polityce lokalnej, angażowanie się w sprawy innych mieszkańców, eksponowanie i afirmowanie tradycji, historii, dziedzictwa miejsca zamieszkania). Ruchy miejskie dość precyzyjne wypracowały kierunki swoich działań zogniskowane wokół: obywatelskości, tożsamości, walki o miasto - pojmowanego jako obszar mający wartość użytkową. Można wyodrębnić następujące cechy tych ruchów: 1) eksponowanie nowego wymiaru obywatelstwa lokalnego - budowanego w odniesieniu do miasta oraz społeczności miejskiej; 2) osadzenie w lokalności i zdefiniowanie terytorialne; 3) zogniskowanie aktyw- 
ności wokół trzech celów: większej dostępności oraz jakości dóbr i usług konsumpcyjnych, tożsamości kulturowej, zaangażowania politycznego (Castells 1982). W kontekście polskiej polityki miejskiej szczegółowe cele ruchów zostały katalogowane podczas cyklicznie następujących po sobie Kongresów Ruchów Miejskich ${ }^{1}$. Wśród najistotniejszych należy wymienić: wprowadzenie budżetów partycypacyjnych, przyznanie prawa do miasta, wzmocnienie mechanizmów demokracji miejskiej, rewitalizacja przestrzeni, walka $\mathrm{z}$ problemami społecznymi (ubóstwem, przestępczością, uzależnieniami, segregacja, wykluczeniem itd.).

Ruchy miejskie powstały w oparciu o paradygmat nowych ruchów społecznych - tym samym charakteryzują się one dwoma podstawowymi cechami. Po pierwsze, więzi łączące uczestników tych ruchów są nieformalne, osobowe, dość zacieśnione, co powoduje, że intensywność i zasięg działań jego członków zależy od natężenia kontaktów i interakcji. Po drugie, uczestnictwo jest dobrowolne i spontaniczne, co w pewnym sensie wynika z rozwoju komunikacji elektronicznej i poszerzających się wpływów globalizacyjnych (Paleczny 2011). Ruchy przyjmują postać niezinstytucjonalizowanych i swobodnych działań (przy użyciu niekonwencjonalnych środków) podjętych w obronie konkretnej sprawy. Główne obszary aktywności to: terytorium fizyczne, warunki i jakość życia, środowisko miejskie, otoczenie sąsiedzkie, dziedzictwo kulturowe, tożsamość (Offe 1995). Istnienie i aktywność ruchu ma istotne znaczenie nie tylko dla jego uczestników, lecz także dla większej zbiorowości. Nadrzędnym celem ruchu jest poszukiwanie alternatywnych rozwiązań bieżących problemów społecznych poprzez zainicjowanie oraz wdrożenie innowacyjnych praktyk i ideologii konstruowanych w obrębie istniejącego systemu. W przypadku ruchów miejskich podstawowym motywem działań jest potrzeba (a jednocześnie prawo) kształtowania tkanki miejskiej. Założenie to polega po pierwsze: na dostosowaniu miasta do faktycznych potrzeb mieszkańców; a po drugie: na rozwiązaniu problemów, jakie pojawiają się w mieście i są postrzegane przez społeczność jako jej zagrażające, destabilizujące lub uniemożliwiające dalsze funkcjonowanie i rozwój. Przykładem są w Polsce Fora Rozwoju, czyli organizacje lokalne postulujące modernizowanie miasta poprzez rozpoczęcie nowych inwestycji w przestrzeni miejskiej. Wśród innych ilustracji efektywnej działalności ruchów można wskazać na Stowarzyszenie My-Poznaniacy, które postuluje strategiczny rozwój miasta (warunkowany przez zrównoważony transport; ekologiczne myślenie; podniesienie jakości życia). Na uwagę zasługują także ruchy warszawskie, ze szczególnym uwzględnieniem Komitetu Obrony Lokatorów, Warszawskiego Stowarzyszenia Lokatorów, które rozwiązują problemy poszkodowanych mieszkańców - np. w wyniku reprywatyzacji kamienic.

Więcej na temat idei i programu Kongresów Ruchów Miejskich oraz trybu ich funkcjonowania i zakresu formalizacji: http://kongresruchowmiejskich.pl/

\section{Konflikt miejski: rola, znaczenie, aktorzy}

Konflikt jest zjawiskiem powszechnym, występującym w różnych społeczeństwach, bez względu na stopień ich rozwoju i organizacji. Odgrywa on istotną rolę w procesie powstawania wspólnot interesów i organizacji, i - jako taki - ma charakter uspołeczniający i scalający grupę: „ludzie jednoczą się, żeby walczyć, i walczy się według uznanych przez obie strony norm i reguł" (Simmel 2008, s. 223). Simmel podkreśla „socjologiczną pozytywność walki” i zalicza konflikt do "czystych form życia społecznego", wskazując tym samym na uniwersalizm czynników konfliktogennych i mechanizmów konfliktotwórczych. Oznacza to, że konflikt może być analizowany niezależnie od kontekstu, w jakim zaistnieje, lub podmiotu, który go wywoła. Formy społeczne nie są stałe i niezmienne, ale podlegają nieustannej fluktuacji w wyniku działań jednostek. Zmienność tych form, a w konsekwencji pojawianie się nowych, wynika ze społecznej potrzeby współoddziaływania i interakcyjności. Konflikt wbrew pozorom nie przynosi wyłącznie negatywnych skutków, lecz jest zjawiskiem korzystnym, sprzyjającym integracji jednostek i umacnianiu wewnętrznej spoistości grupy (Sztompka 2005). W najbardziej ogólnym ujęciu konflikt - jako proces immanentny, złożony, dynamiczny i potencjalnie wzajemny - jest koniecznym warunkiem zawiązania się wspólnoty i dalszego jej trwania.

W socjologicznej literaturze przedmiotu konflikt może być opisywany z perspektywy funkcjonalnej bądź (neo)marksistowskiej². Podejście funkcjonalne opiera się na założeniu, że w każdej grupie społecznej zachodzą w sposób zobiektywizowany i niezależny od sytuacji interakcje konfliktowe (dysocjacyjne). Ich prostą konsekwencją jest dezorganizacja systemu społecznego, a nawet jego rozpad. Obok dysocjacji można wskazać na interakcje asocjacyjne, które integrują elementy systemu, powodując jego scalenie (Turner 2008). To rozróżnienie stanowi punkt wyjścia dla teorii konfliktu Lewisa A. Cosera, który zauważa, iż w każdym układzie społecznym wielokrotnie dochodzi do zachwiania równowagi. Wszystkie te destabilizacje są wywołane ograniczonym dostępem do środków i nieproporcjonalnym podziałem rzadkich dóbr. Konflikt - powstając na tle nierówności ekonomicznych i ideologicznych - jest po pierwsze, walką o dominację w narzuceniu reguł kulturowych (norm i wartości); a po drugie, dążeniem do uzyskania znaczącej pozycji społecznej, dóbr, władzy itd. Zarzewiem sytuacji konfliktowej jest załamanie prawomocności systemu dystrybucji oraz zmobilizowanie się grup podporządkowanych do walki o zasoby i wpływy. W tym kontekście Coser podkreśla pozytywne właściwości konfliktu, zwłaszcza w zakresie integracji i adaptacji międzygrupowej. Konflikt bowiem wzmacnia potencjał grupy oraz stabilność jej struktury, pogłębia poczucie solidarności i więzi po-

2 Obie perspektywy sa przytaczane i rozpatrywane w kategoriach konstruktów teoretycznych - określających podłoże, warunki brzegowe, właściwości i funkcje konfliktu bez względu na typ społeczeństwa w którym ów konflikt pojawia się i rozwija. 
między członkami, zmusza do kreatywności i innowacyjności, podtrzymuje tożsamość zbiorową, wytycza granice poszczególnych grup, skłania jednostki do współdziałania (Coser 2009).

Z kolei podejście (neo)marksistowskie zakłada że w każdym systemie społecznym istnieją dialektyczne sprzeczności, zaś efektem ich nawarstwiania jest właśnie konflikt. Ta opcja teoretyczna stanowi odpowiedź na propagowane przez funkcjonalistów przekonanie, że społeczeństwo stanowi zintegrowany system złożony ze współzależnych i wzajemnie podtrzymujacych się elementów. Krytyka teorii funkcjonalnej dotyczyła rzekomej stabilności systemu społecznego oraz ustawicznego dążenia jednostek do zachowania ładu społecznego, bez względu na poniesione koszty. Jak zauważył Karol Marks, ład społeczny (jeśli w ogóle istnieje) jest trudny do utrzymania oraz zachowania w jednolitej formie. Dzieje się tak dlatego, że ład jest z zasady nietrwały i zmienny, ponieważ stanowi produkt (chwiejnej) równowagi władzy rywalizujących o dominację grup, zaś spójność wynika z przymusu gospodarczego, prawnego, politycznego (Turner 2008). Na tle nierówności w dystrybucji dóbr dochodzi do konfliktu, który zwykle ma podłoże ekonomiczne, bowiem wynika ze sprzeczności interesów grup dominujących i podporządkowanych. Walka klasowa, pojawiająca się wraz ze świadomością swoich potencjalnych praw, wynika z polaryzacji interesów i stosunków międzygrupowych, czego następstwem jest ich pogłębiająca się rozdzielność. Skala konfliktu wpływa na strukturalną zmianę systemu, powodując szerszą redystrybucję rzadkich dóbr - im większy konflikt, tym większe prawdopodobieństwo wyrównanego rozdziału dóbr w systemie (Turner 2008).

Kontynuacją tego myślenia jest koncepcja Ralpha Dahrendorfa, który zauważa, iż w każdej strukturze społecznej istnieją klasy, które są wobec siebie opozycyjne i nastawione konfliktowo (Dahrendorf 2008). Jest tak dlatego, że stratyfikacja powoduje powstanie przeciwstawnych interesów i nierówności w dostępie do władzy, statusu, uznania, bogactwa itd. Konflikty więc odzwierciedlają różnice w podziale dóbr między grupą dominującą a podporządkowaną. Konflikt rozpoczyna się w momencie uświadomienia sobie własnych potrzeb i interesów oraz przeszkód w ich swobodnym zaspokojeniu. Wówczas dochodzi do wyraźnego podziału na grupę dominującą, która może zrealizować swoje interesy, oraz grupę podporządkowaną, która nie ma takiej możliwości. Konflikt ma wiele form i przejawów - „oznacza kontestację, konkurencję, spory, napięcia, jak i otwarte starcie społeczne. Wszelkie relacje między zbiorami jednostek [...], w których istnieje niezgodność i zróżnicowanie celów są relacjami konfliktu społecznego" (Dahrendorf 1993, s. 159). Niezależnie zatem od rodzaju i zasięgu konfliktu, niezbędne dla jego zrozumienia jest dostrzeżenie i nazwanie kontrowersji, jakie powstają w systemie społecznym i destabilizują go strukturalnie lub/i kulturowo. Jeśli więc chcieć zrozumieć istotę konfliktu społecznego, należy uwzględnić motywy konfliktu - nie tylko motywy niezależnie konflikto- genne, lecz także te, które jawia się w świadomości jednostek jako mogące ten konflikt wywołać.

Konflikt społeczny, jako konstrukt pojęciowy, może być konceptualizowany poprzez wskazanie elementów, które go tworzą, lub poprzez przedstawienie stosunków społecznych między tymi elementami (Mucha 1978). Konflikt dotyczy zatem dwóch odmiennych strategii interpretowania działań aktorów społecznych - w zależności od tego, czy punktem wyjścia jest zachowanie i działanie jednostek (z natury rzeczy relacyjne i zmienne) czy ogólnie przyjęta i powszechnie usankcjonowana struktura stanowiąca efekt konsensusów i porozumień zawiązywanych w sytuacjach konfliktowych. W pierwszym przypadku trzeba wziąć pod uwagę, jakie czynniki mogą generować konflikt lub determinują jego zaistnienie. W drugim przypadku - należałoby odpowiedzieć na pytanie, jak wszystkie elementy struktury społecznej, wszelkie systemy i instytucje społeczne można traktować jako układy będące konsekwencją sytuacji konfliktowej. Konflikt jest bowiem czymś więcej niż pewnym typem interakcji, rozumianym jako proste następstwo bodźca wywołującego konflikt i reakcji, która jest odpowiedzią na frustrację czy dyskomfort, owym bodźcem wywołanym. Konflikt jest raczej mechanizmem uruchamiającym cały ciąg procesualnych stosunków społecznych (relacji), które strukturalizują życie codzienne i jako taki może pełnić funkcje naprawcze - być strategią rozwiązywania problemów danej zbiorowości - zarówno tych, które już się pojawiły, jak również tych, które perspektywicznie mogą się pojawić.

Konflikt obejmuje takie zachowania lub sytuacje, kiedy grupa ukierunkowując się na realizację swoich interesów, napotyka przeciwstawne działanie innych grup. Jak wskazuje Szczepański, jest on „serią zjawisk powstających na gruncie rozbieżnych interesów, lub mówiąc dokładniej, jest procesem, w którym jednostka lub grupa dąży do osiągnięcia własnych celów przez wyeliminowanie, podporządkowanie lub zniszczenie jednostki lub grupy dążącej do celów podobnych lub identycznych" (Szczepański 1972, s. 484). Konflikt może stanowić ciąg intencji, rodzaj psychicznego napięcia, strukturalną niezgodność celów bądź interesów stron pojawiających się w sytuacji poczucia krzywdy, niesprawiedliwości (Mucha 1978). Aby konflikt zaistniał oraz wzmacniał swoją dynamikę, potrzebne są dwie zorganizowane zbiorowości - działająca razem i przeciw sobie. Konflikt bowiem z jednej strony wymaga współdziałania członków grupy, która czuje się zdominowana albo pokrzywdzona, zaś z drugiej zaś - konieczna jest grupa opozycyjna, która oponuje i stawia opór. Przedmiotem walki staje się interes grupowy (nie jednostkowy), więc konflikt ma charakter ponadindywidualny, zbiorowy. „Jest on pewnego rodzaju walką, wynikającą z konfrontacji interesów politycznych i ideologicznych. Interesem grupy społecznej nazwiemy obiektywną relację między potrzebami grupy a stanem rzeczy, w którym są realizowane" (Pietras 1989, s. 337). Interesy grup zazwyczaj są rozbieżne pod względem ideologicznym, normatywnym, obyczajowym, poli- 
tycznym, ekonomicznym - tym samym wzajemnie się wykluczają i osiągnięcie konsensusu staje się niemożliwe Jerzy Wiatr wyróżnia sześć typów interesów grupowych, które pojawiają się w systemie: 1) interes klas społecznych, 2) interes narodowości i grup etnicznych, 3) interes grup regionalnych, 4) interes warstw społecznych, 5) interes grup demograficznych, 6) interes grup wyznaniowych (Wiatr 1980). Na tle sprzeczności interesów i odmiennych sposobów ich realizacji dochodzi do napięć, konfrontacji, walki. Jak wskazuje Coleman, konflikt wybucha w sytuacji, kiedy kontrowersja przyjmuje ogólny wymiar - tzn. staje się przedmiotem niezadowolenia większej części zbiorowości, przez co zostaje sklasyfikowana jako problem społeczny wywołujący skrajne emocje i antagonizmy grupowe (za: Starosta 2000). Konflikt powstaje zatem w sytuacji problemowej, gdy pojawiająca się sprzeczność narusza status quo pewnej części zbiorowości, wywołuje ogólnospołecznej poruszenie, skłania do przeciwdziałania.

Konflikt ma swój cykl oraz okres trwania. Paweł Starosta, analizując konflikt lokalny w sensie przyczynowo-skutkowym, wyodrębnia osiem jego faz. Pierwsza polega na pojawieniu się poczucia zagrożenia i niepokoju, które powstało $\mathrm{w}$ następstwie jakiegoś kontrowersyjnego zdarzenia (Starosta 2000). W wyniku konfrontacji stron dochodzi do styczności pomiędzy grupami, co wywołuje negatywne przekonania, że druga grupa przeciwstawia się naszym interesom i zamierzeniom (Kosiński 1989). W fazie drugiej napięcie wywołane owym zdarzeniem narasta, co skutkuje zachwianiem równowagi w danym układzie społecznym. Trzecia faza polega na określeniu stanowisk, jakie zajmują poszczególne grupy w sytuacji konfliktowej. W fazie czwartej dochodzi do wyrażania kontrowersyjnych stanowisk i opinii. W fazie piątej narasta poczucie niesprawiedliwości, co z kolei prowadzi do polaryzacji społeczności. Kolejna faza umożliwia symboliczną kodyfikację oponenta i postawienie granic. Faza siódma polega na przejściu z konfrontacji przedmiotowej („o coś”) do podmiotowej („z kimś”). Końcowa faza ósma to przyjęcie strategii konfliktowej przez poszczególne strony konfliktu (np. dominacja, zimna wojna, izolacja, izolacja, kompromis) (Starosta 2000). Widać zatem, że konflikt ma procesualny charakter, co oznacza, że przebiega etapowo, wedle pewnego scenariusza. Jako proces interakcyjny, wymaga zgromadzenia takiej publiczności i takich aktorów społecznych, którzy są wobec siebie opozycyjni i konkurują o zajęcie najbardziej korzystnej pozycji w strukturze społecznej oraz domagają się pilnej realizacji interesu grupowego.

\section{Ruch miejski jako emanacja konfliktu miejskiego}

W socjologii polityki często zwraca się uwagę na znaczenie ruchów społecznych w procesie rozwiązywania problemów, które zaistniały (lub moga perspektywicznie zaistnieć) w jakiejś, zwykle precyzyjnie wskazanej, społeczności. Akcentowanie roli ruchów w organizacji sfery publicznej i w procesie praktycznego wdrażania zasad demokracji wynika z co najmniej dwóch powodów. Po pierwsze, zauważalny staje się kryzys państwa, które za pośrednictwem zinstytucjonalizowanych mechanizmów nie zaspakaja potrzeb obywali, lekceważy ich interesy oraz nie wychodzi naprzeciw ich oczekiwaniom (związanych np. z opieką społeczną, służbą zdrowia, zabezpieczeniem mienia, gwarancją pracy, ekologią). Po drugie, przyjęty ustrój demokratyczny, oparty na przedstawicielskim modelu reprezentacji politycznej, wydaje się tracić zaufanie i poparcie obywateli. Następstwem tych zjawisk jest brak zainteresowania polityką, a w dalszej kolejności alienacja władzy, jej odseparowanie od realnych problemów, zamknięcie elit politycznych na zewnętrzny głos społeczeństwa, realizacja partykularnych interesów.

Wobec tych zagrożeń ruchy społeczne ukazują możliwość pozainstytucjonalnej formy walki, modernizacji i przeprowadzenia zmiany społecznej poprzez mobilizację zasobów i wykorzystanie potencjału danej zbiorowości (sieci, kompetencji członków, przywództwa, wspólnoty interesów, norm i wartości). Jest tak dlatego, iż ruchy - zgodnie z paradygmatem konstruktywizmu społecznego - stanowią ,jedną z głównych dróg, jaką współczesne społeczeństwa są tworzone od nowa; zbiorowy wysiłek mający na celu modyfikację norm i wartości; przedsięwzięcia o charakterze zbiorowym, mające spowodować zmianę porządku społecznego" (Sztompka 2005, s. 255). Aktorów ruchów społecznych określa się zaś jako „twórców zmiany społecznej; podmioty przekształcające życie polityczne; historyczne jednostki działające; nosicieli projektów historycznych; zbiorowość działającą przez pewien czas w celu propagowania lub przeciwdziałania zmianie w społeczeństwie lub grupie, której ta zbiorowość jest częścią" (Sztompka 2005, s. 256-257). Wszystkie wymienione definicje, bez względu na rozłożenie akcentów, ukazuja cel ruchu, jakim jest przeprowadzenie zmiany w obrębie społeczeństwa pojmowanego jako pewna całość. Skuteczność tej zmiany wynika z poczucia wspólnoty i współdziałania danej zbiorowości - kiedy jednostki wspólnie rozważają kierunek swojego działania oraz pole szans i barier, na którym odbywa się to działanie. Wykształcona tożsamość zbiorowa rodzi skoncentrowane na wspólnocie myślenie (wspólny umysł społeczny), co pozwala określić pewne sytuacje jako niepokojące i wymagające uwagi. Z kolei pobudzenie poznawcze przekłada się na działanie (Griswold 2013) służące realizacji założonych celów i przynoszące spodziewane efekty.

Zawiązanie się ruchu społecznego wynika z wyodrębnienia się w obrębie jakiegoś układu społecznego odrębnych i opozycyjnych wobec siebie grup. Nasilające się kontrowersje i sprzeczności wewnątrzgrupowe uaktywniają mechanizmy konfliktogenne, które z czasem przyjmują postać otwartego konfliktu. Konflikt ten dzieli zbiorowość (skłania bowiem do opowiedzenia się po którejś ze stron), lecz także poszerza spektrum idei i otwiera nowe płaszczyzny ideowej wymiany. Zachodzące wówczas zmiany na poziomie struktury oraz norm i wartości stanowią fragment ewolucji kulturowej, w wyniku której pojawiają się nowe idee (Porta, Diani 2009). W sytuacji, kiedy tradycyjne i utrwalone wzory zachowań przestają wystarczać lub są nieadekwatne do sytuacji - jednostki kwestionują obowiązujący porządek, 
tworząc zręby nowej rzeczywistości. Jak wskazuje Alain Touraine, samo pojęcie ruchu społecznego odnosi się nie tyle do materialnej i obserwowalnej realności, co do sposobu konstruowania rzeczywistości społecznej. Jest tak dlatego, że ruchy stanowią szczególny typ konfliktu społecznego. Konflikt ten opiera się na dychotomicznym podziale na oponentów i zwolenników poróżnionych przez jasno określony obiekt walki lub negocjacji, nad którym obie strony próbują przejąć kontrolę (Touraine 1995). Benjamin Barber twierdzi, że stawką, o jaką toczy się gra w ruchach społecznych, jest narzucenie regulacji w zakresie norm i wartości (Barber 2001). Wspólną cechą konfliktów jest to, że dotyczą one realnych (zorganizowanych) aktorów społecznych oraz, że są ukierunkowane na realizację celów zaplanowanych wcześniej przez uczestników. Konflikty mogą mieć następujące tło: rywalizacja w realizacji interesów zbiorowych, rekonstrukcja tożsamości społeczno-kulturowej, uruchamianie i potęgowanie siły politycznej, obrona posiadanego statusu czy przywilejów, sprawowanie kontroli nad obowiązującymi wzorcami kulturowymi (Touraine 1995). Zawłaszczanie i kolonizacja poszczególnych elementów kultury materialnej (budynków, ulic, urządzeń) lub kultury symbolicznej (języka, przekonań, mody, obyczajów wierzeń, znaczeń) odbywa się za pośrednictwem formalnych procedur lub nieformalnych zabiegów, skutkując przemodelowaniem struktury i kultury danej społeczności. W przypadku ruchów miejskich orientacja na zmianę strukturalną i kulturową jest szczególnie silna - bowiem ruchy te są organizacją aktorów (układu stosunków klasowych), których celem jest spowodowanie jakościowych zmian w systemie. Postulowane zmiany zachodzą równolegle na dwóch płaszczyznach. Po pierwsze, na poziomie struktur - kiedy obejmują przekształcenia strukturalnych elementów dominującego systemu (wynikają ze strukturacji). Po drugie, na poziomie praktyk dotyczą wówczas zmian stosunków władzy i dominacji (Castells 1982). W odniesieniu do wizji Castellsa można tu mówić o walce klas, które konkurują o dostęp do środków i produktów konsumpcji oraz prawo do kreowania aktualnych wzorów konsumpcyjnych. Ruchy miejskie są odpowiedzią na walki klasowe zachodzące w systemie miejskim, w wyniku których dochodzi do konfrontacji i sprzeczności. Spory te mają charakter kumulatywny i są podłożem utworzenia się ruchu - „miejski ruch społeczny powstaje w wyniku nagromadzenia się sprzeczności strukturalnych wewnątrz systemu miejskiego" (Castells 1982, s. 283). Następstwem tego procesu jest konflikt, którego zakres zależy wprost proporcjonalnie od wartości dóbr lub rangi usług będących przedmiotem sporu.

Ruch miejski jest wyrazem rożnych form sprzeciwu, zwłaszcza wobec nierównej dystrybucji dóbr, takich jak: usługi, transport, mieszkalnictwo, miejsca praca, szkoły, żłobki. Do konfliktu może więc dochodzić wśród różnych grup, formacji i podmiotów społecznych, w zróżnicowanych systemach polityczno-ekonomicznych. Stopień mobilizacji grupowej, która wpływa na tempo, zakres i ilość przeprowadzonych zmiany, zależy od skumulowania się sprzeczności. Im większy konflikt i szersza jego skala, tym silniejsze sieci i wpływy ruchów miejskich - przede wszystkim dlatego, iż ruchy zyskują do dyspozycji większą liczbę środków kontroli, przymusu i nacisku. Poza tym zwiększa się samoorganizacja i samopomoc obywatelska wobec grup marginalizowanych i wykluczonych, co z kolei umożliwia ewolucyjną lub rewolucyjną zmianę miasta lub zmianę $\mathrm{w}$ mieście.

\section{Miasto jako obszar konfliktu społecznego}

Badacze przestrzeni społecznej zwracają uwagę, iż stanowi ona wytwór historii oraz ludzkich działań i artefaktów (rolnictwa, rzemiosła, przemysłu). Na przestrzeń tym samym można patrzeć jako na rezultat aktywności człowieka, podziałów pracy, ról i pozycji, które charakteryzują daną społeczność pod względem demograficznym, statusowym, kulturowym itd. To społeczeństwo tworzy przestrzeń, nadaje jej swoiste cechy i elementy, które pozwalają odróżnić ją od innych, nadać specyfikę, uczynić wyjątkową. W tym sensie przestrzeń staje się obiektywizacją zarówno tego, co społeczne, jak i tego, co duchowe, idealne (m.in. Jałowiecki, Szczepański 2002; Wódz 1989). Patrząc na przestrzeń przez pryzmat współczynnika humanistycznego, trzeba ją traktować jako wytwór podmiotów ludzkich, którzy nadają jej pewne sensy, przypisują jakieś znaczenia. Przestrzeń jest zawsze czyjaś, do kogoś należy, gdyż stanowi obszar ludzkiego doświadczenia i działania (Znaniecki 2005). Przestrzeń społeczna - w odróżnieniu od naturalnie ukształtowanej - nie powstaje w sposób bezwolny czy organiczny, jest natomiast reprodukowana przez pojedynczych lub zbiorowych aktorów, którzy identyfikują się z nią lub do niej przynależą. Jeśli więc przestrzeń jest konstruowana społecznie, to stanowi układ odniesienia dla porządku społecznego - jest miejscem produkcji, konsumpcji, wymiany; władzy i dominacji; nośnikiem reguł kulturowych uznanych i powielanych przez zbiorowość. Tworząc przestrzeń, aktorzy społeczni jednocześnie ją zawłaszczają (w znaczeniu dosłownym i metaforycznym) - co oznacza, że stają się jej właścicielami, określają warunki jej istnienia i funkcjonowania, jej obraz obecny i przyszły.

Wśród różnych typów przestrzeni na szczególną uwagę zasługuje miasto, którego powstanie stanowi efekt intensywnie zachodzących procesów urbanizacji, stymulowanych przez rozwój handlu i kapitalizm. Jak zaznacza David Harvey, „miasta [...] pojawiły się dzięki geograficznej i społecznej koncentracji produktu dodatkowego. Jako że nadwyżki zawsze wyciskano skądś lub z kogoś [...], natomiast kontrolę nad ich wydatkowaniem sprawowało zazwyczaj niewielu, urbanizacja zawsze była zjawiskiem o charakterze klasowym" (Harvey 2012, s. 1). Miasto stało się nie tylko przestrzenią życia codziennego, lecz także miejscem kumulacji kapitału, produkcji, dystrybucji, konsumpcji i wynikających z niej podziałów (Urbański 2011). Wszystkie te procesy spowodowały, iż przestrzeń miejska to pole ujawniania się napięć, sprzeczności, kontrowersji, walk, konfliktów. Konfliktotwórczy oraz konfliktogenny charakter miasta skłania do odczytywania i rozumienia miasta według paradygmatu konfliktowego. Podejście 
konfliktowe w socjologii miasta jest znane i stosunkowo dobrze ugruntowane pod względem teoretycznym i metodologicznym, gdyż - jak przypomina Andrzej Majer - socjologia miasta jest naznaczona antynomią neosimellowskiej wizji konfliktów rozgrywających się w mieście oraz neomarksowskiej wykładni konfliktów wywołanych przez miasto jako system przestrzenny i społeczny. Obie perspektywy łączy założenie, że konflikty stanowią nieuchronny element życia w mieście i są integralnym składnikiem postępujących procesów urbanizacji i industrializacji (Majer 2000). Przy czym trzeba podkreślić, iż konflikty miejskie zwykle wywołują negatywne konotacje, co ma swoje uzasadnienie w licznych narracjach antymiejskich, szczególnie popularnych w XVIII i XIX wieku. Antyurbanizm polega nie tyle na negatywistycznej waloryzacji miasta, co na apoteozie wsi - przestrzeni postrzeganej jako sielska, swojska, moralna, tradycyjna (Rybicka 2003). Pesymistyczny obraz miasta jest także podtrzymany w aglomeracyjnych wizjach Georga Simmela, który uznaje mieszkańców wielkich miast za aspołecznych, egoistycznych, wyobcowanych, zorientowanych wyłącznie na zarabianie pieniędzy i mnożenie zysku. Wielkie miasto - pisze Simmel - opiera się na bezosobowej kalkulacji i gospodarce pieniężnej, którą cechuje „bezlitosna rzeczowość, wyrachowany ekonomiczny egoizm, zajmujący miejsce wartości i uczuć" (Simmel 2005, s. 307). Kontynuację tej myśli można odnaleźć w książce Davida Riesmana, Nathana Glazera, Richarda Denneya, których Samotny tłum jest metaforą życia w mieście rządzonego przez anonimowość, korozję więzi towarzyskich i rodzinnych, brak zaangażowania w sprawy społeczności. Antropologiczne spojrzenie na miasto pozwala twierdzić, iż miasto generuje liczne patologie, zwłaszcza ubóstwo i „kulturę biedy” (za: Majer 2000).

Konflikt miejski może być rozpatrywany jako szczególny typ konfliktu społecznego, ponieważ miasto jest jednocześnie obiektem i obszarem sytuacji konfliktowej (walka toczy się w mieście i o miasto). „Dwupoziomowość” konfliktu wynika z faktu, iż miasto jest rozumiane w znaczeniu terytorialnym (fizycznym) jako wydzielony administracyjnie obszar, lecz także (a nawet przede wszystkim) jako przestrzeń kulturowa, którą dana społeczność zamieszkuje, postrzega jako własną, tworząc i odtwarzając tam pewne praktyki społeczne. Przestrzeń miejska określa repertuar wartości symbolicznych, normatywnych i materialnych, które są podstawą działań zbiorowych. Miasto nie jest tylko formalnie wydzieloną całością geograficzną lub historycznym tworem ze specyficzną tradycją, mitologią, obrzędowością, ale zbiorem działań, praktyk i reguł społeczno-kulturowych, które fluktuują, przenikają się i dążą do uzyskania symbolicznej dominacji. Miasto jest więc terytorium walk, nie tyle w sensie dosłownym, co symbolicznym. Konflikt staje się właściwością miasta, nieodzowną cechę jego istnienia, jako zorganizowanej wedle pewnych reguł całości. Jest tak dlatego, iż miasto implikuje szereg takich zależności, które w zobiektywizowany sposób są dysocjacyjne. Castells, opisując mechanizmy konfliktów miejskich, zwraca uwagę na stratyfikacje społeczne, klasowość i wynikające z nich podziały i nierówności. Postrzega miasta jako historyczne manifestacje siły i produkcji kapitalistycznej. Przestrzeń miejską uznaje za kolektywną przestrzeń konsumpcji, która odzwierciedla dominującą ideologię i działania władzy, będąc jednocześnie formą jej legitymizacji (Castells 1982). Innymi słowy: miasto to produkt społeczny, który jest efektem konfliktu interesów, celów i wartości. Jako że interesy poszczególnych grup nie są ze sobą zbieżne, a wręcz pozostają w opozycji, konflikt rośnie w siłę i angażuję coraz większą liczbę osób w nim partycypujących. W ten sposób dokonuje się wyraźny podział społeczeństwa na klasy różnice się wobec siebie sytuacją rynkową, statusowa, zawodową. Stratyfikacje, wynikające z zajmowania odmiennych miejsc $\mathrm{w}$ procesie produkcji i konsumpcji, powodują narastanie nierówności społecznych. Ponieważ nierówności wykazują tendencje do pogłębiania się, stają się coraz bardziej zauważalne oraz dotkliwie odczuwane przez członków poszkodowanej (czyli dyskryminowanej lub tłumionej) grupy społecznej. Nastający wówczas nastrój kontestacji i buntu wobec niesprawiedliwej akumulacji kapitału stanowi tło do wyłonienia się ruchu miejskiego ukierunkowanego na idee sprawiedliwości i równości społecznej. Ruch ten powstaje w opozycji do wszelkich prób dominacji klasowej, narzucenia władzy, nadużyć klasy panującej, strategicznej akumulacji kapitałów, „gdy to gospodarka akumulacji bogactwa niesiona jest na ramionach brutalnej ekonomii opartej o wywłaszczenia” (Harvey 2012, s. 49). Ruch miejski budowany jest w oparciu o hasło „prawa do miasta”, które - jak podkreśla David Harvey - jest „czymś o wiele szerszym niż prawo dostępu jednostki lub grupy do zasobów, które zawiera miasto; jest prawem do zmiany i wynajdywania miasta na nowo takim, jakim go pragniemy. Jest też, co więcej, prawem bardziej kolektywnym niż indywidualnym, ponieważ wynajdywanie miasta na nowo w sposób nieunikniony zależy od sprawowania kolektywnej władzy nad procesem urbanizacji" (Harvey 2012, s. 22). Prawo do miasta przynależy każdej jednostce i powinno być rozpatrywane jako podstawowe prawo człowieka (podobnie jak np. prawo do wolności, godności). Co więcej: „spośród praw kolektywnych właśnie prawo do miasta może okazać się najcenniejszym dobrem, a przy tym, paradoksalnie, nadal najbardziej lekceważonym" (Harvey 2012, s. 22).

Ruchy miejskie koncentrują swoją aktywność wokół konfliktowej idei „prawa do miasta” - interpretowanej jako prawo do „zmieniania świata, zmieniania życia i do wymyślenia miasta na nowo zgodnie z ich [ludzi - J.T.] pragnieniami" (Harvey 2012, s. 49). Innowacje w strukturze i kulturze miejskiej są możliwe dzięki mobilizacji i współpracy miejskich aktywistów, którzy podejmują próby przekształcenia miasta (wywołania zmian w systemie miejskim, instytucjach kulturalnych i samorządowych, utworzenia alternatywnych dyskursów, utworzenia budżetu partycypacyjnego, wdrożenia inicjatyw zbiorowych). Działalność ta polega na świadomym i kolektywnym działaniu dotyczącym różnych spraw miejskich (np. socjalnych lub urbanistycznych). Ruchy powstają jako odpowiedź na kryzys wynikający z sytuacji konfliktowej, kiedy napięcia i walki powodowane sprzecznością interesów skutkują deprecjacją jakiejś grupy 
lub uniemożliwiają jej trwanie i rozwój. Miasto jest kształtowane przez pojawiające się w nim konflikty, a jednocześnie miasto - jako system - przekształca konflikty w nowe podsystemy społeczne i przestrzenne. W przypadku ruchów miejskich żądanie prawa do miasta oraz walka o miasto jest elementem działalności antykapitalistycznej, alternatywą dla globalizacji i mainstreamowej polityki neoliberalnej.

\section{Konkluzje}

Konflikty występują w każdej grupie i przestrzeni społecznej, mają zatem charakter uniwersalistyczny i ogólnospołeczny. Ich zakres, natężenie, formy zależą od jego przyczyn oraz grup, które te konflikty inicjują lub/i w nich uczestniczą. W przypadku konfliktów miejskich głównym mechanizmem wywołującym napięcia i sprzeczności (czyli ich stymulatorem) są podziały i nierówności wynikające z nieproporcjonalnej dystrybucji dóbr lub niewłaściwej akumulacji kapitału. W tej sytuacji konflikt służy nie tylko zaakcentowaniu tych nierówności (a co za tym idzie poczucia niesprawiedliwości i krzywdy), lecz także rozszerza pole interakcji i negocjacji podejmowanych w celach redystrybucyjnych. Zwykle podłożem konfliktu miejskiego są niezgodności w interesach pojedynczych lub zbiorowych aktorów, którzy uzurpują sobie prawo do miasta (deweloperów, polityków, działaczy, aktywistów, inwestorów, przedsiębiorców, właścicieli budynków, rentierów). Różnice interesów wzmagają roszczenia poszczególnych grup, a w przypadku niemożliwości lub niechęci ich zaspokojenia budzą agresję i przemoc w znaczeniu symbolicznym (narzucanie reguł kulturowych) albo - i wcale nierzadko - w znaczeniu dosłownym (stosowanie gróźb lub naruszeń nietykalności fizycznej, czego niechlubnym przykładem są czyściciele kamienic).

Konflikt jest skuteczną strategią rozwojową i modernizacyjną dla współczesnego miasta. Zaistnienie sytuacji konfliktowej wywołuje przekształcenia strukturalne i kulturowe, przede wszystkim dlatego, że konflikt kształtuje politykę miejską (wymusza reakcje i działania ze strony podmiotów politycznych i ekonomicznych sprawujących władzę). Konflikt opiera się na mechanizmach wywierania wpływu i efektywnego oddziaływania na siebie skonfliktowanych stron. Sytuacja konfliktowa aktywuje i mobilizuje społeczeństwo do działania, zwiększa partycypację, sprzyja integracji i łączeniu sił, ułatwia wywieranie nacisku na decydentów, umożliwia identyfikację i ekspozycję problemów, przez co nabierają one charakteru publicznego (a więc przestają być osobiste i prywatne). Zdolność mobilizacji jednostek w celu skutecznego wpływania na władzę lokalną staje się wskaźnikiem samoorganizacji i podmiotowości obywatelskiej, ponieważ prowadzi do „wprowadzenie konkretnych zmian w miejscu zamieszkania, bądź też stworzenia platformy udziału mieszkańców w podejmowaniu ważnych decyzji dotyczących społeczności" (Lewenstein 2001, s. 107). Konflikt, jako ogół planowych i konsekwentnych działań, dynamizuje proces demokratyzacji i de- liberacji, gdyż uruchamia myślenie o mieście w kategoriach wspólnoty interesów, norm, wartości. Mimo że konflikt początkowo wywołuje negatywne emocje oraz antagonizuje stosunki międzyludzkie (w niektórych przypadkach narusza przyjęty ład społeczny), to w efekcie integruje społeczność. Na konflikt należy zatem patrzeć nie tylko jak na wybuch niechęci i frustracji, lecz jak na mechanizm spajający zbiorowość. Jest tak dlatego, iż sytuacja konfliktowa ujawnia szerokie spektrum problemów społecznych, które są postrzegane jako zagrażające, a tym samym wymagające natychmiastowego rozwiązania (a w perspektywie długookresowej - zapobiegnięcia im). Konflikt wywołany gniewem obywateli wzmacnia oddziaływania na ośrodki władzy, które mogą i powinny podjąć instytucjonalne działania interwencyjne i prewencyjne. Konflikt oznacza więc o wiele więcej niż tylko tymczasowe i powierzchowne działanie pozorowane. Jak podkreśla Dahrendorf, „nowoczesny konflikt społeczny nie dotyczy już usunięcia różnic. [...] nowoczesny konflikt społeczny jest walką z nierównościami, które ograniczają pełne obywatelskie uczestnictwo środkami społecznymi, ekonomicznymi lub politycznymi; powoduje konieczność ustanowienia uprawnień, które składają się na bogaty i pełny status obywatelskości" (Dahrendorf 1973, s. 72-73). W wyniku konfliktów dochodzi do przekształceń w obrębie systemu miejskiego - zyskuje on nowe możliwości i funkcje (powstają instytucje, tworzą się sieci społeczne i grupy wsparcia, wykorzystuje się innowacyjne modele kierowania i koordynacji). Poszerzone w ten sposób forum polityki miejskiej umożliwia realizacje następujących celów: stworzenie reguł zarządzania miastem poprzez współpracę różnych grup interesu; budowanie kapitału obywatelskiego opartego na zaufaniu, współdziałaniu, trosce o los współmieszkańców; sformułowanie misji, programów strategicznych i planów inwestycyjnych, których wdrożenie przyczyni się do rozwoju miasta i podniesie jakość życia jego mieszkańców.

Wykorzystanie konfliktu przez ruchy miejskie, niebędące jednak wyrazem niechęci współpracy i eliminowania problemów, lecz skuteczną formą ich manifestacji oraz potrzeby rozwiązania, wydaje się skutecznym sposobem rozwoju miast, ponieważ uwzględnia zróżnicowane interesy mieszkańców i przedstawia różne formy ich artykulacji. W zależności od kontekstu oraz aktorów społecznych wystąpienie konfliktu jest szczególnie uzasadnione - „wybór między konfliktem a konsensusem jako odpowiedniej strategii działania zależy od rozeznania najbardziej prawdopodobnej reakcji najważniejszych interesariuszy na próby wprowadzania zmian oraz doboru najwłaściwszych sposobów odpowiedzi na ich reakcje" (za: Skrzypiec 2010, s. 124). Strategia konfliktowa wzmacnia te komponenty rozwoju struktury i kultury miejskiej, które wynikają nie tyle z rentowności i efektywności gospodarowania, co z umiejętności krystalizowania i argumentowania zajmowanego stanowiska, woli negocjacji i konfrontacji z grupą opozycyjną. 


\section{Literatura:}

1. Barber B.R. (2001), Dżihad kontra McŚwiat. Muza, Warszawa.

2. Castells M. (1982), Kwestia miejska. PWN, Warszawa.

3. Coser L.A. (2009), Funkcje konfliktu społecznego. Nomos, Kraków.

4. Dahrendorf R. (1973), Nowoczesny konflikt społeczny. Esej o polityce wolności. Czytelnik, Warszawa.

5. Dahrendorf R. (2008), Klasy i konflikt klasowy w społeczeństwie przemysłowym. Nomos, Kraków.

6. Giddens A. (2006), Socjologia. PWN, Warszawa.

7. Griswold W. (2013), Socjologia kultury. Kultury i społeczeństwa w zmieniajacym się świecie. PWN, Warszawa.

8. Harvey D. (2012), Bunt miast. Prawo do miasta i miejska rewolucja. Fundacja Nowej Kultury Bęc Zmiana, Warszawa.

9. Jacobs J. (2014), Śmierć i życie wielkich miast Ameryki. Wyd. CA, Warszawa.

10. Jałowiecki B., Szczepański M.S. (2002), Miasto i przestrzeń w perspektywie socjologicznej. Scholar, Warszawa.

11. Kosiński S. (1989), Socjologia ogólna. Zagadnienia podstawowe. PWN, Warszawa.

12. Lewenstein B. (2001), Obywatelskie strategie i modele wprowadzania zmiany społecznej w miejskich społecznościach lokalnych - doświadczenia amerykańskie, W: M. Warowicki, Z. Wozniak (red.), Aktywność obywatelska w rozwoju społeczności lokalnej. Od komunikacji do wspótpracy. Municypium, Warszawa, s. $105-115$.

13. Majer A. (2000), Konflikty miejskie. Próba rozwinięcia tematu, W: M. Malikowski, Z. Seręga (red.), Konflikty społeczne w Polsce w okresie zmian systemowych. Wyd. WSP, Rzeszów, s. 81-92.

14. Mucha J. (1978), Konflikt i społeczeństwo. PWN, Warszawa.

15. Offe C. (1995), Nowe ruchy społeczne: przekraczanie granic polityki instytucjonalnej, W: J. Szczupaczyński (red.), Władza i społeczeństwo. Scholar, Warszawa, s. 22-230.

16. Paleczny T., Nowe ruchy społeczne $w$ warunkach globalizacji, W: K. Derwich, M. Kania (red.), Ruchy społeczne i etniczne. Wyd. UJ, s. 9-25.

17. Porta D., Diani M. (2009), Formy i repertuary działań oraz cykle protestu, W: Ruchy społeczne. Wyd. UJ, Kraków, s. 14-15.

18. Rybicka E. (2003), Modernizowanie miasta. Universitas, Kraków.

19. Simmel G. (2005), Socjologia. PWN, Warszawa.

20. Simmel G. (2008), Pisma socjologiczne. Oficyna Wydawnicza, Warszawa.

21. Skrzypiec R. (2010), Konflikt jako strategia rozwiqzywania problemów w społecznościach lokalnych, W: B. Lewenstein, J. Schindler, R. Skrzypiec (red.), Partycypacja społeczna i aktywizacja w rozwiqzywania problemów społeczności lokalnych. Wyd. UW, Warszawa, s. 115-125.

22. Starosta P. (2000), Konflikt lokalny, W: M. Malikowski, Z. Seręga (red.), Konflikty społeczne w Polsce w okresie zmian systemowych. Wyd. WSP, Rzeszów, s. 13-24.

23. Sterniczuk B. (1979), Nowe obszary zainteresowań zachodnioeuropejskiej socjologii miasta. Studia Socjologiczne, 4 (75), s. 99-122.

24. Szczepański J. (1972), Elementarne pojęcia socjologii. PWN, Warszawa.

25. Sztompka P. (2005), Socjologia zmian społecznych. Znak, Kraków.

26. Sztompka P. (2005), Socjologia. Analiza społeczeństwa, Znak, Kraków.

27. Touraine A. (1995), Wprowadzenie do analizy ruchów społecznych, W: J. Szczupaczyński (red.), Władza i społeczeństwo. Scholar, Warszawa, s. 212-214.

28. Turner J.H. (2008), Struktura teorii socjologicznej. PWN, Warszawa.

29. Urbański J. (2011), Fabryka versus agora. Szkic z ekonomii politycznej miasta, W: M. Nowak, P. Pluciński (red.), O miejskiej sferze publicznej. obywatelskość i konflikty o przestrzeń. Ha!art, Kraków, s. 240-256.

30. Wiatr J.J. (1980), Socjologia stosunków politycznych. PWN, Warszawa.

31. Znaniecki F. (2005), Fakty i przedmioty kulturowe, W: P. Sztompka, M. Kucia (red.), Socjologia. Lektury. Znak, Kraków, s. 61-63. 